\title{
Effect of Prophylactic Antibiotic Use in the Development of Antibiotic Resistance in Children with Recurrent Urinary Tract Infections
}

\author{
Tekrarlayan Idrar Yolu Enfeksiyonunda Profilaktik Amaçlı Antibiyotik Kullanımının \\ Çocuklarda Antibiyotik Direnç Gelişimine Etkisi
}

\author{
Mehmet Karacı, Kazım Karagöz*, Zühal Örnek* , Adem Yaşar** , Necla Yüce, Özgür Okumuş \\ University of Health Sciences Fatih Sultan Mehmet Training and Research Hospital, Clinic of Pediatrics, Istanbul, Turkey \\ *Bülent Ecevit University Faculty of Medicine, Department of Pediatrics, Zonguldak, Turkey \\ **Bozok University Faculty of Medicine, Department of Pediatrics, Yozgat, Turkey
}

\section{Abstract}

\begin{abstract}
Aim: Although prophylactic antibiotic treatment is still debatable, it is currently in use in recurrent urinary tract infections (UTIS). In the present study, we aimed to observe if prophylactic antibiotic use had any effect on the development of antibiotic resistance in patients with recurrent UTIs who we followed up in our clinic.

Methods: The present study was performed on patients aged between one month and 16 years, who had recurrent UTIs, and were followed up by the Department of Pediatrics at Bülent Ecevit University Medical School. Patient files were retrospectively reviewed, and 50 patients who received antibiotic prophylaxis and 100 patients without prophylaxis were enrolled in the study. Urinary tests, subsequent urinary culture results, and antibiotic resistances were compared between the groups.
\end{abstract}

Results: The mean age was $42.7 \pm 44.2$ months. The most frequently cultured isolated bacterium was Escherichia coli (E. coli) (58.4\%). No difference was determined in bacteria in cultures between prophylaxis receivers and non-receivers. Isolation rate of $E$. coli was higher in urinary cultures in females than in males $(p<0.001)$. When antibiotic resistance of all urinary culture-isolated bacteria was compared between the two groups, there was no statistically significant difference. However, an increased resistance against amoxicillin/clavulanic acid, ceftriaxone, and piperacillin was determined in prophylaxis group in whom $E$. coli was grown. In this study, general antibiotic resistance was most frequently observed against ampicillin (71.9\%).

Conclusion: In the present study, we observed that prophylaxis did not contribute so much to resistance other than $E$. coli. We recommend not preferring antibiotics which have increased resistance in our institution especially in children receiving prophylaxis for empirical treatment.

Keywords: Childhood, urinary tract infection, prophylaxis, antibiotic resistance
Amaç: Tekrarlayan idrar yolu enfeksiyonlarında (IYE) antibiyotik proflaksisi günümüzde tartışmalı da olsa kullanılmaya devam edilmektedir. Biz bu çalışmada, kendi kliniğimizde takip ettiğimiz tekrarlayan IYE'de kullanılan profilaksinin antibiyotik direnç gelişimine etkisinin olup olmadığını gözlemlemeyi amaçladık.

Yöntemler: Bu çalışma Bülent Ecevit Üniversitesi Tıp Fakültesi Pediatri Departmanı'nca takip edilen bir ay ile 16 yaş arası tekrarlayan idrar yolu enfeksiyonu olan hastalarda yapılmıştır. Hasta dosyaları retrospektif olarak taranarak antibiyotik proflaksisi alan 50 ve almayan 100 hasta çalışmaya dahil edildi. Hastaların idrar tetkikleri, sonraki kültürlerindeki üremeleri ve bunların antibiyotik dirençleri gruplar arasında karşılaştırıldı. Bulgular: Hastaların \%43,3 erkek, \%56,7 kızlardan oluşmaktaydı ve ortalama yaşları $42,7 \pm 44,2$ ay (1 ay-16 yaş) idi. Tüm kültürlerde en sık üreyen bakteri \%58,4 ile Escherichia Coli (E. coli) idi. Profilaksi alan ve almayan gruplar arasında kültürde üreyen bakterilerin dağılımı açısından bir fark saptanmadı. Kızlardaki idrar kültürlerinde $E$. coli görülme oranı erkeklerden daha fazlaydı $(p<0,001)$. Her iki grupta idrar kültürlerinde üreyen tüm bakterilerin antibiyotiklere direnci karşılaştırıldığında istatistiksel olarak anlamlı fark görülmedi. Buna karşın profilaksi grubunda idrar kültüründe $E$. coli üreyenlerde amoksisilin/klavulanik asit, seftriakson ve piperasiline karşı artmış direnç saptandı. Bu fark istatistiksel olarak anlamlı bulundu. Bu çalışmada da en sık antibiyotik direnci \%71,9 ile ampisiline karşı gözlendi.

Sonuç: Biz bu çalışmada E. coli dışındaki ajanlarda proflaksinin dirence çok katkısının olmadığını gözlemledik. Kendi hastanemizde özellikle proflaksi alan bir çocuk için ampirik tedavide direnç artışı saptanan antibiyotiklerin tercih edilmemesini önermekteyiz.

Anahtar Sözcükler: Çocukluk çağı, idrar yolu enfeksiyonu, proflaksi, antibiyotik direnci
Address for Correspondence/Yazışma Adresi: Mehmet Karacı

University of Health Sciences Fatih Sultan Mehmet Training and Research Hospital, Clinic of Pediatrics, İstanbul, Turkey

Phone: +90 5327868187 E-mail: mkaraci@gmail.com ORCID ID: orcid.org/0000-0002-8774-2562

Received/Geliş Tarihi: 12 December 2016 Accepted/Kabul Tarihi: 05 April 2017
'Copyright 2017 by The Medical Bulletin of University of Health Sciences Haseki Training and Research Hospital

The Medical Bulletin of Haseki published by Galenos Yayınevi.

${ }^{\circledR}$ Telif Hakkı 2017 Sağlık Bilimleri Üniversitesi Haseki Eğitim ve Araştırma Hastanesi Haseki Tıp Bülteni, Galenos Yayınevi tarafindan basılmıştır. 


\section{Introduction}

Urinary tract infection (UTI) is the second most commonly encountered infectious disease following upper respiratory tract infection in children (1). UTIs is an important cause of morbidity in childhood. Antibiotic therapy is generally initiated empirically because early treatment decreases the rate of morbidity resulting from UTIs $(2,3)$. Although prophylactic antibiotic use for recurrent UTIs is decreasing nowadays, it still is in the use (4-6). However, antibiotic resistance has become an increasingly pressing problem in many countries. Moreover, there are considerable geographic variations in bacterial patterns and resistance properties depending on local antimicrobial prescription practices (3). Additionally, it is believed that prophylactic antibiotic use contributes to drug resistance.

The aim of the present study was to determine causative microorganisms in our institution in recurrent UTI cases in our clinic, etiological factors, and whether prophylactic antibiotic use had any effects on resistance development.

\section{Methods}

\section{Design, Setting, and Participants}

This was a retrospective case-control study conducted in the Department of Pediatrics, Bülent Ecevit University School of Medicine, between January 2008 and January 2013. A total of 150 patients (100 receiving no prophylaxis, and 50 receiving prophylaxis) aged between one month and 16 years, who were diagnosed with recurrent UTI in our clinic, were enrolled in the study. All patients were investigated for UTI causes. Additionally, all had population-based UTI. Antibiotic resistance rates in later urinary cultures were compared between the groups who satisfied recurrence criteria and was followed up without prophylactic antibiotic use. In addition, other tests and demographic characteristics of the patients were evaluated retrospectively.

\section{Study Content}

Urine samples were provided after perineal cleaning in children with urinary control by mid-flow urine sampling, and by catheterization in children without urinary control, and all samples were incubated in appropriate media. Suprapubic aspiration was performed in none of our patients for sampling. For biochemical analysis, noncentrifuged fresh urine samples were used. Acidity, density, leukocyte and neutrophil counts, and nitrite reaction were performed. An insight xpert u500 device was used for these data. In microscopic examination, urine samples were first centrifuged, and examined at x40 magnification there were 5 or more leukocytes in one microscopic field, then it was diagnosed as pyuria; five or more erythrocytes per field was diagnosed as hematuria; and any number of bacteria was diagnosed as bacteriuria. Urine samples were inoculated into blood agar and eosin methylene blue agar (GBL, Turkey), and were incubated at $37^{\circ} \mathrm{C}$ for 18-24 hours. After the inoculation, grown up bacteria were determined according to classical methods and/ or appropriate $\mathrm{API}^{\circledR}$ identification system (BioMerieux, France) after colony counting. The level of significance was determined as $\geq 10^{5}$ colony-forming units (CFU)/mL for mid-flow urine and $\geq 10^{4} \mathrm{CFU} / \mathrm{mL}$ for catheter cultures, if children had clinical signs.

Antibiotic sensitivities were determined by using agar disc diffusion technique. After spreading bacterial suspension prepared in 0.5 McFarland over Müller-Hinton agar (GBL, Turkey), antibiotic discs (Bioanalyse, Turkey) were used. Bacterial sensitivities were assessed according to the Clinical and Laboratory Standards Institute criteria. According to antibiogram results, antibiotics were separated into two groups as susceptible and resistant. Trimethoprim-sulfamethoxazole (TMP-SMX), amoxicillin, nitrofurantoin, and cefixime were used according to patient age in antibiotic prophylaxis. Urinary ultrasound, voiding cystourethrogram and Tc-99m Dimercaptosuccinic acid scintigraphy were used as imaging techniques.

\section{Statistical Analysis}

Statistical analyses were performed with SPSS 18.0 software (SPSS Inc., Chicago, IL, USA). Continuous variables were expressed as mean \pm standard deviation and categorical variables as frequency and percent. Continuous variables were compared with the independent samples t-test and categorical variables were compared using the Pearson chi-square test or Fisher's exact test. A p value of less than 0.05 was considered statistically significant for all tests.

The present study was approved on 3rd September 2014 by Local Ethics Committee of Zonguldak Bülent Ecevit University (approval number: 2013/14).

\section{Results}

In the present study, 235 culture growths from 150 patients, who had population-based UTIs recurred within approximately five-years, were retrospectively screened in medical files and documented.

Demographic characteristics of the groups: Of the subjects, 65 (43.3\%) were male, and 85 (56.7\%) were female. The mean age of the patients was $42.7 \pm 44.2$ months (1 month-16 years). There was no difference between the groups in gender distribution and age (Table 1). The indication for prophylaxis was vesicoureteral reflux $(n=11 ; 22 \%)$, neurogenic bladder $(n=2 ; 4 \%)$, renal anomalies ( $n=10 ; 20 \%)$, renal calculus $(n=5 ; 10 \%)$, and 
voiding dysfunction $(n=4 ; 8 \%)$; the other 18 children (36\%) had idiopathic recurrent UTI.

Correlation of biochemical examination of urine with cultural positivity: In both groups, Escherichia coli (E. coli) was the most common ( $\mathrm{n}=137,58.4 \%)$ bacterium among causative agents. In prophylaxis receiving group, E. coli was more commonly isolated compared to the other agents in the presence of leukocyte esterase in urine $(p=0.017)$. However, no correlation was determined in other parameters (bacteriuria, pyuria, hematuria, and nitrite). Moreover, there was no similar correlation between urine analysis and culture bacteria isolated in prophylaxis non-receivers. The mean number of cultural growth was $2 \pm 2.32$ and $1 \pm 1.19$ in prophylaxis receivers and no-receivers, respectively $(p<0.001)$.

Distribution of isolated bacteria in groups receiving and non-receiving prophylaxis: There was no significant difference in bacterial growth in urine cultures between prophylaxis receivers and non-receivers. The distribution of cultured microorganisms is given in Table 2 .

\begin{tabular}{|l|l|l|l|l|l|l|}
\hline \multicolumn{7}{|c|}{ Table 1. Gender distribution of groups } \\
\hline \multirow{2}{*}{ Gender } & Prophylaxis & \multicolumn{2}{|c|}{ No prophylaxis } & \multirow{2}{*}{ Total } & p \\
\cline { 2 - 6 } & $\mathbf{n}$ & $\%$ & $\mathbf{n}$ & $\%$ & & \\
\hline Male & 22 & 44 & 43 & 43 & 65 & \multirow{2}{*}{1.000} \\
\hline Female & 28 & 56 & 57 & 57 & 85 & \\
\hline Total & 50 & 100 & 100 & 100 & 150 & \\
\hline
\end{tabular}

Table 2. The distribution of isolated bacteria in the urine cultures

\begin{tabular}{|c|c|c|c|c|c|c|c|c|}
\hline & \multicolumn{2}{|c|}{ Prophylaxis } & \multicolumn{2}{|c|}{$\begin{array}{l}\text { No } \\
\text { prophylaxis }\end{array}$} & \multicolumn{2}{|c|}{ Total } & \multirow[t]{2}{*}{$p$} \\
\hline \multirow{10}{*}{ 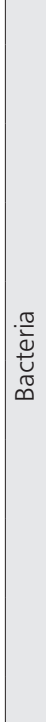 } & & $\mathbf{n}$ & $\%$ & $\mathbf{n}$ & $\%$ & $\mathrm{n}$ & $\%$ & \\
\hline & $\begin{array}{l}\text { Escherichia } \\
\text { coli }\end{array}$ & 60 & 51.3 & 77 & 65.3 & 137 & 58.4 & \multirow{9}{*}{$p>0.05$} \\
\hline & $\begin{array}{l}\text { Klebsiella } \\
\text { pneumoniea }\end{array}$ & 18 & 15.4 & 21 & 17.8 & 39 & 16.6 & \\
\hline & $\begin{array}{l}\text { Proteus } \\
\text { mirabilis }\end{array}$ & 13 & 11.1 & 11 & 9.3 & 24 & 10.2 & \\
\hline & $\begin{array}{l}\text { Pseudomonas } \\
\text { spp. }\end{array}$ & 12 & 10.2 & 1 & 0.8 & 13 & 5.5 & \\
\hline & $\begin{array}{l}\text { Klebsiella } \\
\text { oxytoca }\end{array}$ & 6 & 5.1 & 4 & 3.4 & 10 & 4.3 & \\
\hline & $\begin{array}{l}\text { Enterobakter } \\
\text { auerogenes }\end{array}$ & 6 & 5.1 & 3 & 2.6 & 9 & 3.8 & \\
\hline & $\begin{array}{l}\text { Morganella } \\
\text { morganii }\end{array}$ & 1 & 0.9 & 1 & 0.8 & 2 & 0.8 & \\
\hline & $\begin{array}{l}\text { Serratia } \\
\text { marcescens }\end{array}$ & 1 & 0.9 & 0 & 0.0 & 1 & 0.4 & \\
\hline & Total & 117 & 100 & 118 & 100 & 235 & 100 & \\
\hline
\end{tabular}

In order of frequency, E. coli, Klebsiella spp., and Proteus mirabilis were determined.

Distribution of bacteria among genders in prophylaxis receivers and non-receivers: $E$. coli was the most commonly isolated bacteria both in males and females. Isolation rate of $E$. coli was $34.5 \%$ in males and $79.2 \%$ in females. Majority of patients with E. coli were females, and it was more common than males $(p<0.001)$ (Table 3) (Graphic 1).

Distribution of age range according to gender in children with isolated bacteria: Of patients with UTI, $41.5 \%(n=27)$ of males were $\leq 1$ year old; whereas $80 \%$ ( $n=68$ ) of females were $\geq 13$ months old. UTI rate was increased in males younger than one year of age, and in females older than one year of age $(p=0.007)$ (Table 4$)$.

Distribution rate of antibiotics used in prophylaxis: There were a total of 50 patients in the prophylaxis receiving group, and $62.0 \%$ of them were receiving TMP-SMX, 28.0\% were receiving amoxicillin, 8.0\% were receiving nitrofurantoin, and $2.0 \%$ were receiving cefixime.

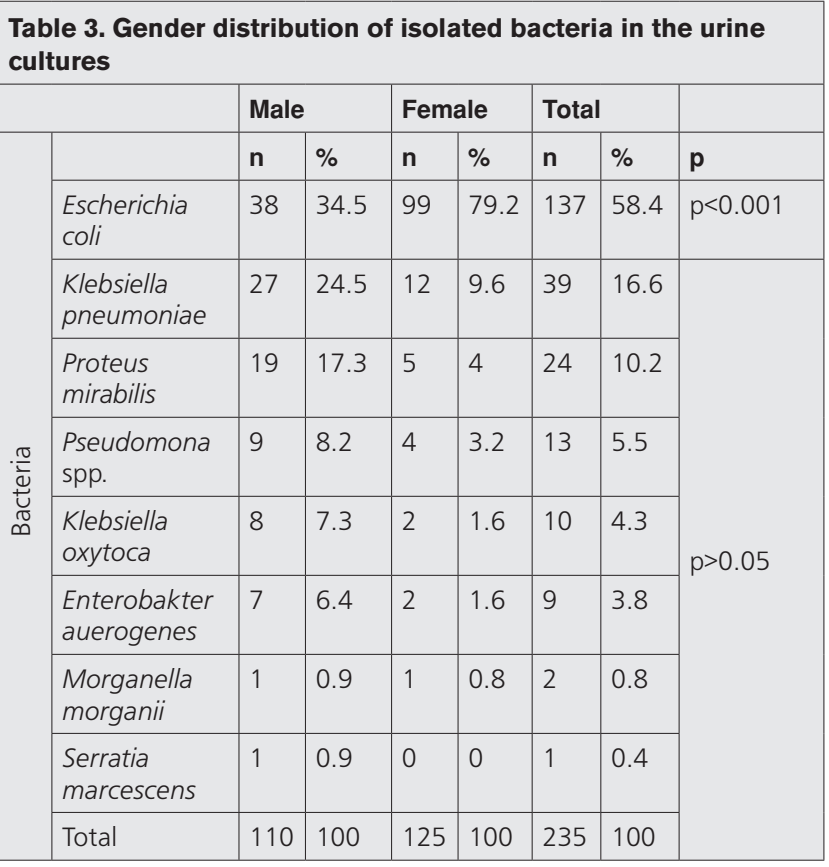

Table 4. Distribution of age range according to gender in children with urinary culture

\begin{tabular}{|l|l|l|l|l|l|l|l|}
\hline \multirow{2}{*}{ Age (years) } & \multicolumn{4}{|c|}{ Gender } & \multicolumn{2}{c|}{ Total } & \multirow{2}{*}{ p } \\
\cline { 2 - 6 } & \multicolumn{2}{|c|}{ Male } & \multicolumn{2}{|c|}{ Female } & \multicolumn{2}{c|}{} \\
\cline { 2 - 6 } & $\mathbf{n}$ & $\%$ & $\mathbf{n}$ & $\%$ & $\mathbf{n}$ & $\%$ & \\
\hline$\leq 1$ year & 27 & 41.5 & 17 & 20.0 & 44 & 29.3 & \multirow{2}{*}{0.007} \\
\hline$>1$ year & 38 & 58.5 & 68 & 80.0 & 106 & 70.7 & \\
\hline Toplam & 65 & 100 & 85 & 100 & 150 & 100 & \\
\hline
\end{tabular}




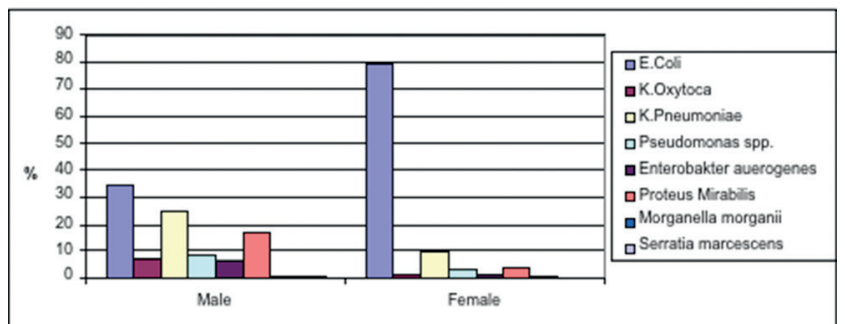

Graphic 1. Gender distribution of isolated bacteria in the urine cultures

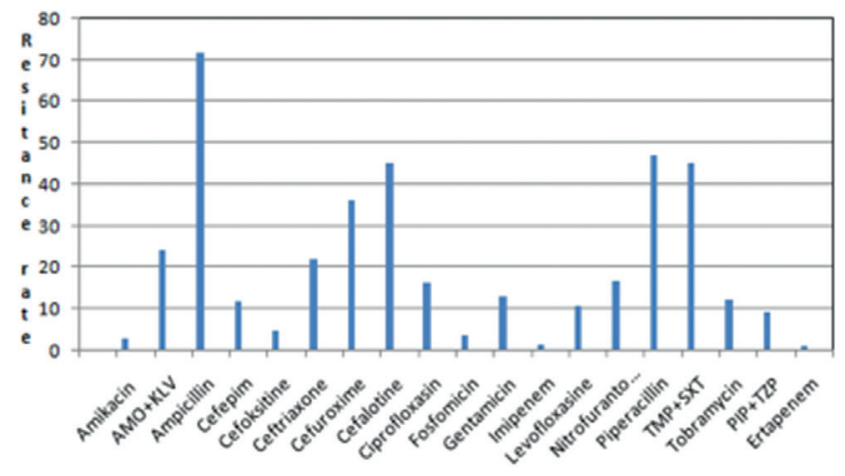

Graphic 2. The over all rate of antibiotic resistance in patients (\%) AMO+CLV: Amoxicillin +clavulanic acid, TMX+SXT: Trimethoprim+sulfametaxazole, PIP+TZP: Piperacilline+tazobactam

Mean antibiotic resistance rate in all patients: Total resistance rate of bacteria which were isolated in urine cultures was determined as $71.9 \%$ for ampicillin, $47.0 \%$ for piperacillin, $45.3 \%$ for cefalotin, $45.1 \%$ for TMPSMX, $4.9 \%$ for cefoxitin, $3.7 \%$ for fosfomycin, $2.9 \%$ for amikacin, $1.4 \%$ for imipenem, and $1.0 \%$ for ertapenem (Graphic 2).

Antibiotic resistance differences in cultures between prophylaxis receivers and non-receivers: When all grown up agents were evaluated together, there was no difference in resistance development for abovementioned antibiotics between prophylaxis receivers, and non-receivers. Namely, having started prophylactic antibiotic treatment did not have any effect on antibiotic resistance development of microorganisms, which were later in urine cultures.

Effects of causative microorganisms in urine culture in antibiotic resistance development: Increased resistance against amoxicillin/clavulanic acid (AMO/CLV) (37.5-8.7\%), ceftriaxone (34.6-10.4\%) and piperacillin (71.4-39.9\%) was determined in patients who had E. coli in subsequent urine cultures and were receiving prophylaxis, when compared with prophylaxis non-receivers (Table 5). There was no significant difference in drug resistance between patients having Klebsiella spp. in the two groups. As the number of other bacteria grown was fewer, statistical analysis was not performed.

\section{Discussion}

Currently, empirical antibiotic treatment is recommended in all patients, who are suspected to have UTI, to start early treatment, and decrease morbidity rate. Treatment and prophylaxis plans should be performed according to regional UTI agents, and antimicrobial resistance patterns $(2,7)$. It has been reported that UTI is more commonly encountered in female gender. (2) In a study on recurrent UTI, the rate of recurrent infection was found to be $68.2 \%$ in females and $57.4 \%$ in males, and it was determined that $42.9 \%$ of male children with the diagnosis of UTI were younger than one year of age; as age increased UTI rate was significantly decreased among these patients (8). Similar to that study, $43.3 \%$ of patients in our cohort were male, and $56.7 \%$ were female. There was no difference in gender distribution between the groups. Similar to the literature, we detected that UTI rate was increased in male children younger than one year, and in female children older than one year of age (8-11). In the present study, E. coli was more frequent than other agents in the presence of leukocyte esterase than in its absence in biochemical examination of urine in prophylaxis receiving group $(p=0.034)$, whereas such a relationship was not found in the prophylaxis non-receiving group.

In a large-scale study, it was shown that resistance developed against prophylactic antibiotics, and chemoprophylaxis could not prevent recurrence of UTI $(2,5)$. We observed that prophylaxis did not decrease the rate of UTI recurrence. The mean number of growth in urinary culture was $2 \pm 2.32$ in prophylaxis receivers, and $1 \pm 1.19$ in non-receivers. However, we believe that standardized patient studies (etiological cause, prophylactic antibiotic etc.) are required to clarify this issue.

In studies performed all over the world, E. coli, Klebsiella spp., and Proteus spp. are determined in the first three lines $(7,9,12-15)$. Similar to the literature, it was determined in the present study that $E$. coli $(58.4 \%)$ was the most commonly isolated microorganism both in females and males in both groups. It was followed by Klebsiella spp. (20.9\%), and Proteus spp. (10.2\%). No difference was determined in isolated bacteria between the two groups. Although the most commonly isolated agent was $E$. coli in both genders, majority of patients with $E$. coli were females (Table 3 ). Frequent empiric treatment of UTI increases the importance of antibiotic susceptibility characteristics of agents $(3,16)$. In many countries, the most common antibiotic resistance in isolated species is against ampicillin. The probability of resistance development against ampicillin was determined as $45 \%, 50 \%$, and $100 \%$ in children living in Canada, Europe, and Africa, respectively (17-20). Ampicillin is not recommended alone in the treatment of UTIS, 


\begin{tabular}{|c|c|c|c|c|c|c|c|c|}
\hline \multirow[t]{3}{*}{ Antibiotic } & & \multicolumn{6}{|c|}{ Escherichia coli } & \multirow{3}{*}{$p$} \\
\hline & \multirow[t]{2}{*}{ No prophylaxis } & & \multicolumn{2}{|c|}{ Prophylaxis } & \multicolumn{2}{|l|}{ Total } & & \\
\hline & & $\%$ & $\mathbf{n}$ & $\%$ & $\mathbf{n}$ & $\%$ & & \\
\hline \multirow{3}{*}{ Amikacin } & Antibiotic-sensitive & 64 & 98.5 & 25 & 92.6 & 89 & 96.7 & \multirow{3}{*}{0.205} \\
\hline & Antibiotic-resistant & 1 & 1.5 & 2 & 7.4 & 3 & 3.3 & \\
\hline & Total & 65 & 100 & 27 & 100 & 92 & 100 & \\
\hline \multirow{3}{*}{$\mathrm{AMO}+\mathrm{CLV}$} & Antibiotic-sensitive & 42 & 91.3 & 10 & 62.5 & 52 & 83.9 & \multirow{3}{*}{0.014} \\
\hline & Antibiotic-resistant & 4 & 8.7 & 6 & 37.5 & 10 & 16.1 & \\
\hline & Total & 46 & 100 & 16 & 100 & 62 & 100 & \\
\hline \multirow{3}{*}{ Ampicillin } & Antibiotic-sensitive & 28 & 40.6 & 6 & 22.2 & 34 & 35.4 & \multirow{3}{*}{0.146} \\
\hline & Antibiotic-resistant & 41 & 59.4 & 21 & 77.8 & 62 & 64.6 & \\
\hline & Total & 69 & 100 & 27 & 100 & 96 & 100 & \\
\hline \multirow{3}{*}{ Cefepim } & Antibiotic-sensitive & 56 & 94.9 & 19 & 82.6 & 75 & 91.5 & \multirow{3}{*}{0.092} \\
\hline & Antibiotic-resistant & 3 & 5.1 & 4 & 17.4 & 7 & 8.5 & \\
\hline & Total & 59 & 100 & 23 & 100 & 82 & 100 & \\
\hline \multirow{3}{*}{ Cefoksitine } & Antibiotic-sensitive & 68 & 98.6 & 24 & 96.0 & 92 & 97.9 & \multirow{3}{*}{0.463} \\
\hline & Antibiotic-resistant & 1 & 1.4 & 1 & 4.0 & 2 & 2.1 & \\
\hline & Total & 69 & 100 & 25 & 100 & 94 & 100 & \\
\hline \multirow{3}{*}{ Ceftriaxone } & Antibiotic-sensitive & 60 & 89.6 & 17 & 65.4 & 77 & 82.8 & \multirow{3}{*}{0.012} \\
\hline & Antibiotic-resistant & 7 & 10.4 & 9 & 34.6 & 16 & 17.2 & \\
\hline & Total & 67 & 100 & 26 & 100 & 93 & 100 & \\
\hline \multirow{3}{*}{ Cefuroxime } & Antibiotic-sensitive & 39 & 81.3 & 13 & 59.1 & 52 & 74.3 & \multirow{3}{*}{0.094} \\
\hline & Antibiotic-resistant & 9 & 18.8 & 9 & 40.9 & 18 & 25.7 & \\
\hline & Total & 48 & 100 & 22 & 100 & 70 & 100 & \\
\hline & Antibiotic-sensitive & 37 & 69.8 & 11 & 50.0 & 48 & 64.0 & \\
\hline Cefalotin & Antibiotic-resistant & 16 & 30.2 & 11 & 50.0 & 27 & 36.0 & 0.173 \\
\hline & Total & 53 & 100 & 22 & 100 & 75 & 100 & \\
\hline & Antibiotic-sensitive & 61 & 88.4 & 19 & 73.1 & 80 & 84.2 & \\
\hline Ciprofloxasin & Antibiotic-resistant & 8 & 11.6 & 7 & 26.9 & 15 & 15.8 & 0.111 \\
\hline & Total & 69 & 100 & 26 & 100 & 95 & 100 & \\
\hline & Antibiotic-sensitive & 64 & 98.5 & 23 & 100 & 87 & 98.9 & \\
\hline Fosfomisin & Antibiotic-resistant & 1 & 1.5 & 0 & 0.0 & 1 & 1.1 & 1.000 \\
\hline & Total & 65 & 100 & 23 & 100 & 88 & 100 & \\
\hline & Antibiotic-sensitive & 61 & 91.0 & 22 & 84.6 & 83 & 89.2 & \\
\hline Gentamicin & Antibiotic-resistant & 6 & 9.0 & 4 & 15.4 & 10 & 10.8 & 0.458 \\
\hline & Total & 67 & 100 & 26 & 100 & 93 & 100 & \\
\hline & Antibiotic-sensitive & 67 & 98.5 & 27 & 100 & 94 & 98.9 & \\
\hline Iminenem & Antibiotic-resistant & 1 & 1.5 & 0 & 0.0 & 1 & 1.1 & 1.000 \\
\hline mimpenem & Total & 68 & 100 & 27 & 100 & 95 & 100 & \\
\hline & Antibiotic-sensitive & 60 & 87.0 & 22 & 84.6 & 82 & 86.3 & \\
\hline Levofloxasin & Antibiotic-resistant & 9 & 13.0 & 4 & 15.4 & 13 & 13.7 & 0.747 \\
\hline & Total & 69 & 100 & 26 & 100 & 95 & 100 & \\
\hline & Antibiotic-sensitive & 67 & 100 & 24 & 100 & 91 & 100 & \\
\hline Nitrofurantoin & Antibiotic-resistant & - & - & - & - & - & - & - \\
\hline & Total & 67 & 100 & 24 & 100 & 91 & 100 & \\
\hline & Antibiotic-sensitive & 37 & 60.7 & 6 & 28.6 & 43 & 52.4 & \\
\hline Piperacilline & Antibiotic-resistant & 24 & 39.3 & 15 & 71.4 & 39 & 47.6 & 0.022 \\
\hline . & Total & 61 & 100 & 21 & 100 & 82 & 100 & \\
\hline
\end{tabular}


Karacı et al. Antibiotic Resistance in Children with Recurrent Urinary Tract Infections

\begin{tabular}{|c|c|c|c|c|c|c|c|c|}
\hline \multirow{3}{*}{$\mathrm{TMX}+\mathrm{SXT}$} & Antibiotic-sensitive & 38 & 55.9 & 13 & 48.1 & 51 & 53.7 & \multirow{3}{*}{0.650} \\
\hline & Antibiotic-resistant & 30 & 44.1 & 14 & 51.9 & 44 & 46.3 & \\
\hline & Total & 68 & 100 & 27 & 100 & 95 & 100 & \\
\hline \multirow{3}{*}{ Tobramycin } & Antibiotic-sensitive & 47 & 90.4 & 17 & 81.0 & 64 & 87.7 & \multirow{3}{*}{0.269} \\
\hline & Antibiotic-resistant & 5 & 9.6 & 4 & 19.0 & 9 & 12.3 & \\
\hline & Total & 52 & 100 & 21 & 100 & 73 & 100 & \\
\hline \multirow{3}{*}{$\mathrm{PIP}+\mathrm{TZP}$} & Antibiotic-sensitive & 44 & 95.7 & 15 & 93.8 & 59 & 95.2 & \multirow{3}{*}{1.000} \\
\hline & Antibiotic-resistant & 2 & 4.3 & 1 & 6.3 & 3 & 4.8 & \\
\hline & Total & 46 & 100 & 16 & 100 & 62 & 100 & \\
\hline \multirow{3}{*}{ Ertapenem } & Antibiotic-sensitive & 44 & 95.7 & 15 & 93,8 & 59 & 95.2 & \multirow{3}{*}{-} \\
\hline & Antibiotic-resistant & 2 & 4.3 & 1 & 6.3 & 3 & 4.8 & \\
\hline & Total & 46 & 100 & 16 & 100 & 62 & 100 & \\
\hline
\end{tabular}

because of high risk of resistance development (21). In a study conducted in the United Kingdom, it was almost recommended that routine antibiotic prophylaxis should be stopped in children having UTI $(5,22)$.

The rate of resistance against ampicillin ranged between $64.9 \%$ and $88 \%$ in studies performed in Turkey and in the world $(7,9,23-29)$. When antibiotic resistance in all patients was reviewed in the present study, the resistance rates were determined as $71.9 \%$ for ampicillin, $47.0 \%$ for piperacillin, $45.1 \%$ for TMP-SMX, $24.2 \%$ for $\mathrm{AMO} / \mathrm{CL}$, and $22.1 \%$ for ceftriaxone. We recommend that antibiotics with lower resistance rates should be selected for empiric treatments for UTI in our institution.

Ampicillin resistance of $E$. coli was determined as 50$70 \%$, and TMP+SMX was $31.2-53 \%$ in previous studies $(3,7,18,30)$. In a study, cefotaxime resistance in $E$. coli was significantly higher in patients receiving prophylaxis when compared with non-receivers. However, there was no increase in aminoglycoside resistance in these patients (31). Different from the former study, receiving prophylaxis did not change any microorganisms in later cultures in the present study. It was also determined that resistance was more commonly determined for AMO/ $C L V$, ceftriaxone, and piperacillin in patients who had $E$. coli isolated in urine cultures, and received prophylaxis than the non-receivers (Table 5). However, there was no difference in resistance for other antibiotics between the groups. There was no significant difference in antibiotic resistance in patients having Klebsiella growth between the two groups. In conclusion, we recommend that these three antibiotics should be selected neither orally nor parenterally as empiric antibiotic in the prophylaxis, since $E$. coli is the most commonly isolated agent.

Currently, there is no consensus in the world on criteria for initiating prophylaxis. Low-dose, long-term prophylaxis is still being recommended in patients with high renal scarring risk $(2,5,6,32)$. However, antimicrobials in prophylaxis may increase the risk of development of resistance $(5,22,31,33)$.

Although there are many data about UTI and antibiotic resistance in the literature, there are limited data indicating that prophylaxis might increase antibiotic resistance. In a study performed in two centers, previous urine culture results in 420 patients who received prophylaxis were compared. It was determined in both hospitals that $E$. coli infection rate was decreased in patients receiving antibiotic prophylaxis when compared with that in those with a previous UTI (23). However, there were significant decreases in susceptibility of all $3^{\text {rd }}$ generation cephalosporins, ciprofloxacin, gentamicin, and amikacin in patients receiving cephalosporins prophylaxis and significant decreases were determined in susceptibility of gentamicin and ciprofloxac in in patients receiving TMPSXT prophylaxis (23). In the study, initiation of prophylaxis caused neither $E$. coli nor other bacteria in later cultures.

The design of the present study was different from the study mentioned above. We had a total of 50 patients who received prophylaxis. As the number of patients for each prophylactic antibiotic was fewer, we compared groups as prophylaxis receivers and non-receivers. When antibiotic resistances of isolated bacteria in all urine cultures were compared in both groups, there was no statistically significant difference in increase of resistance. Thus, initiation of prophylaxis did not affect antibiotic resistance in later cultures. As there are few such designed studies in the literature, we believe that large-scale prospective studies should be performed to define any correlation between prophylaxis and resistance development.

In a study performed in Iran, it was shown that resistance was developed against antibiotic used for prophylaxis in more than half of patients with resistant UTI, who received previous prophylaxis (28). In the 
present study, we did not observe increased resistance against antibiotics used in the prophylaxis in later cultures between the groups. However, resistance rate is generally increasing against prophylactic antibiotics in our institution

\section{Study Limitations}

Limitations of our study may be summarized as the patients might have used another antibiotic rather than prophylactic antibiotic previously for an infection other than the urinary system, and this might have affected susceptibility of UTI agent. Patient compliance was not definite for prophylactic antibiotics. Moreover, we did not divide patients into groups according to their underlying etiological factors, as well as we did not divide them according prophylaxis duration. Considering these factors, well-standardized prospective studies are required for the future. Similar to the world, we believe that inappropriate antibiotic use may contribute to increased antibiotic resistance also in our region.

\section{Conclusion}

In the present study, on the contrary to the common belief, we observed that prophylaxis did not increase antibiotic resistance in later urine cultures, and the rates were similar between the groups. However, we also determined increased resistance rates against $\mathrm{AMO} / \mathrm{CLV}$, ceftriaxone, and piperacillin in the prophylaxis group if $E$. coli was isolated in the culture. We recommend that empiric antibiotics should be selected considering these results and general antibiotic resistance rates in similar patients as in our institution. Consequently, we recommend that resistance studies specific for every regions should be performed and empiric treatments should be designed under the light of the study results.

\section{Ethics}

Ethics Committee Approval: The present study was approved on 3rd September 2014 by Local Ethics Committee of Zonguldak Bülent Ecevit University (approval number: 2013/14).

Informed Consent: Retrospective study.

Peer-review: Externally and internally peer-reviewed.

\section{Authorship Contributions}

Surgical and Medical Practices: M.K. Concept: M.K., K.K. Design: M.K., K.K. Data Collection or Processing: M.K., K.K., Z.Ö. Analysis or Interpretation: M.K., Z.Ö., A.Y. Literature Search: M.K., K.K., N.Y., Ö.O. Writing: M.K., Ö.O.

Conflict of Interest: No conflict of interest was declared by the authors.
Financial Disclosure: The authors declared that this study received no financial support.

\section{References}

1. Hansson S, Jodal U. Urinary tract infection. In: Avner ED, Harmon WE, Niaudet P, editors. Pediatric Nephrology, Philadelphia: Lippincott Williams \&Wilkins; 2004. p. 1007-27.

2. Subcommittee on Urinary Tract Infection, Steering Committee on Quality Improvement and Management, Roberts KB. Urinary tract infection: clinical practice guideline for the diagnosis and management of the initial UTI in febrile infants and children 2 to 24 months. Pediatrics 2011;128:595-610.

3. Yüksel S, Oztürk B, Kavaz $A$, et al. Antibiotic resistance of urinary tract pathogens and evaluation of empirical treatment in Turkish children with urinary tract infections. Int J Antimicrob Agents 2006;28:413-6.

4. Santen SA, Altieri MF. Pediatric urinary tract infections. Emerg Med Clin North Am 2001;19:675-90.

5. Mori R, Lakhanpaul M, Verrier-Jones K. Diagnosis and management of urinary tract infection in children: summary of NICE guidance. BMJ 2007;335:395-7.

6. Newman TB. The new American Academy of Pediatrics urinary tract infection guideline. Pediatrics 2011;128:572-5.

7. Yılmaz R, Karaaslan E, Özçetin M, Arslan B, Kılınç M, Kazancı NÖ. Agents of urinary tract infections in children and their antibiotic susceptibility. J Contemp Med 2012;2:17-21.

8. Akçay T, Taskın N, Akçay A, et al. Üriner sistem infeksiyonlarına tanısal yaklasım. İstanbul Tıp Derg 2004;1:27-30.

9. Aydemir C, Aydemir H, Polat R, Pişkin iE. Pediatrik yaş grubunda üriner sistem enfeksiyonuna sebep olan üropatojenlerin dağı̆ımının ve antibiyobiyal dirençlerinin değerlendirilmesi. Klimik Derg 2008;21:118-21.

10. Keskinoğlu A, Mir S. The effect of recurrent urinary tract infections on somatic growth in children. Turk Arch Ped 2008;43:139-42.

11. No authors listed. Practice parameter: the diagnosis, treatment, and evaluation of the initial urinary tract infection in febrile infants and young children. American Academy of Pediatrics. Committee on Quality Improvement. Subcommittee on Urinary Tract Infection. Pediatrics 1999;103:843-52.

12. Alpay $H$, Göknel $G$, Bilgen $N$. Çocukluk çağı üriner sistem infeksiyonlarında etken mikroorganizmalar ve antibiyotik duyarlııkları. ANKEM Derg 1995;9:118-23.

13. McLoughin TG Jr, Joseph MM. Antibiotic resistance patterns of uropathogens in pediatric emergency department patients. Acad Emerg Med 2003;10:347-51.

14. Karimian M, Kermani R, Khaleghi M, Kelishadi R, Ataei B, Mostafavi N. Antibiotic susceptibility patterns of isolates from children with urinary tract infection in Isfahan, Iran: Impact on empirical treatment. J Glob Antimicrob Resist 2017;9:3-7.

15. Brandström P, Hansson S. Long-term, low-dose prophylaxis against urinary tract infections in young children. Pediatr Nephrol 2015;30:425-32. 
16. Hryniewicz K, Szczypa K, Sulikowska A, Jankowski K, Betlejewska K, Hryniewicz W. Antibiotic suspectibility of bacterial strains isolated from urinary tract infections in Poland. J Antimicrob Chemother 2001;47:773-80.

17. Adjei O, Opoku C. Urinary tract infections in African infants. Int J Antimicrob Agents 2004;24(Suppl 1):32-4.

18. Allen UD, MacDonald N, Fuite L, Chan F, Stephens D. Risk factors for resistance to 'first-line' antimicrobials among urinary tract isolates of Escherichia coli in children. CMAJ 1999;160:1436-40.

19. Haller M, Brandis M, Berner R. Antibiotic resistance of urinary tract pathogens and rationale for empirical intravenous therapy. Pediatr Nephrol 2004;19:982-6.

20. Ladhani S, Gransden W. Increasing antibiotic resistance among urinary tract isolates. Arch Dis Child 2003;88:444-5.

21. Carapetis JR, Jaquiery AL, Buttery JP, et al. Randomized, controlled trial comparing once daily and three times daily gentamicin in children with urinary tract infections. Pediatr Infect Dis 2001;20:240-6.

22. Hajibagheri K, Priesemann M, Morrison I, Parikh A, Lessof N, Price E. NICE guidance on urinary tract infection in children abandons routine antibiotic prophylaxis. Arch Dis Child 2008;93:356.

23. Cheng $\mathrm{CH}$, Tsai $\mathrm{MH}$, Huang $\mathrm{YC}$, et al. Antibiotic resistance patterns of community-acquired urinary tract infections in children with vesicoureteralreflux receiving prophylactic antibiotic therapy. Pediatrics 2008;122:1212-7.

24. Gürgöze MK, Doğan Y, Kizirgil A, Toraman ZA, Aygün D. İdrar yolu enfeksiyonlu çocuklardan elde edilen bakterilerin çeşitli antibiyotiklere duyarlılıkları. Fırat Tıp Derg 2002;7:828-32.
25. Ergüven M, Talay S, Babaoğlu K, Toprak A, Takman Ş, Özilen S. Çocuklarda idrardan izole edilen bakterilerin çeşitli antibiyotiklere duyarlılıkları. İnfeksiyon Derg 1990;4:571-7.

26. Gür D, Kanra G, Ceyhan M, Seçmeer G, Kanra B, Kaymakoğlu I. Epidemiology and antibiotic resistance of gram-negative urinary pathogens in pediatric patients. Turk J Pediatr 1999;4:37-42.

27. Tosun SY, Demirel MM, Ertan P, Aksu S. Çocuklara ait idrar örneklerinden izole edilen bakterilerin antibiyotik duyarlılıkları. Turkiye Klinikleri J Pediatr 2004;13:59-62.

28. Nateghian AR, Robinson JL, Mohandessi S, Hooman N. Resistance pattern of breakthrough urinary tract infections in children on antibiotic prophylaxis. J Infect Public Health 2009;2:147-52.

29. Ili T, Gra an S, Arapovi A, Capkun V, Subat-Dežulovi M, Saraga M. Changes in bacterial resistance patterns in children with urinary tract infections on antimicrobial prophylaxis at University Hospital in Split. Med Sci Monit 2011;17:355-61.

30. Cesur S, Albayrak F, Özdemir D, Kolcu Z, Tekeli E. Hastanede yatan hastaların idrar örneklerinden izole edilen gram negatif çomakların antibiyotiklere duyarlılıkları. Türk Mikrobiyol Cem Derg 2002;32:174-76.

31. Lutter SA, Currie ML, Mitz LB, Greenbaum LA. Antibiotic resistance patterns in children hospitalized for urinary tract infections. Arch Pediatr Adolesc Med 2005;159:924-8.

32. Tekgül $S$, Riedmiller $H$, Hoebeke $P$, et al. EAU guidelines on vesicoureteral reflux in children. Eur Urol 2012;62:534-42.

33. Mori R, Fitzgerald A, Williams C, Tullus K, Verrier-Jones $K$, Lakhanpaul M. Antibiotic prophylaxis for children at risk of developing urinary tract infection: a systematic review. Acta Paediatr 2009;98:1781-6. 